\title{
DOE/PC/92160-T/4
}

\section{ENGINEERING DEVELOPMENT OF ADVANCED COAL-FIRED LOW-EMISSIONS BOILER SYSTEMS}

\author{
Project Technical Status Report
}

\author{
QUARTERLY REPORT \\ For the Period of: \\ April 1996 to June 1996
}

July 1996

2063 3963

Submitted by:

Babcock \& Wilcox Company

Contract Research Division

1562 Beeson Street

Alliance, Ohio 44601

Prepared for:

United States Department of Energy

U.S. DOE Reference DE-AC22-92PC92160

B\&W Reference: CRD 1319

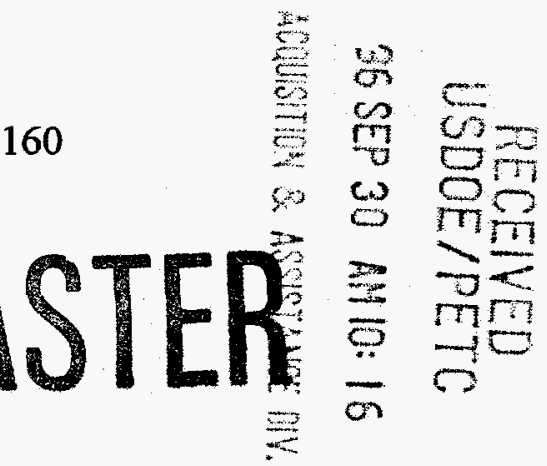


"This report was prepared by Babcock \& Wilcox pursuant to a contract partially funded by the U. S. Department of Energy and neither Babcock \& Wilcox, nor any of its subcontractors nor the U. S. Department of Energy, nor any person acting on behalf of either:

(a) makes any warranty or representation, expressed or implied, with respect to the accuracy, completeness, or usefulness of information contained in this report, or that the use of any information, apparatus, method, or process disclosed in this report may not infringe privately owned rights; or

(b) assumes any liabilities with respect to the use of, or for damages resulting from the use of, any information, apparatus, method or process disclosed in this report.

Reference herein to any specific commercial product, process, or service by trade name, trademark, manufacturer, or otherwise, does not necessarily constitute or imply its endorsement, recommendation, or favoring by the U. S. Department of Energy. The view and opinions of authors expressed herein do not necessarily state or reflect those of the U. S. Department of Energy." 


\section{DISCLAIMER}

Portions of this document may be illegible electronic image products. Images are produced from the best available original document. 


\section{Project Management}

Proposal efforts to the North Dakota Lignite Research Council (NLRC), Ohio Coal Development Office (OCDO) to gain their funding participation in the B\&W LEBS Phase IV proof-of-concept demonstration are in progress. In addition, a prospectus and letter requesting consideration for funding by the State of Illinois "Office of Coal Development and Marketing" was sent. Illinois has already committed to support the Riley/S\&L team for Phase IV if they win the award. B\&W is asking for support if we win. In support of development of these proposals the costs and scope of the Phase IV effort is being updated.

A meeting with the LEBS Advisory Board was held on May 17. An update of the progress being made on the project was provided along with a tour of the Clean Environment Development Facility (CEDF) which is being utilized as the Subsystem Test Facility for Task 11. Discussions were open and many good comments and suggestions were received.

A status meeting was held with the U.S. DOE on May 31. A review of the subsystem activities was provided along with a tour of the CEDF. Plans for Phase IV activities were also discussed.

The following technical papers were submitted; "Evaluation of Microwave, Acoustic, and Hot Film Sensors for the Measurement of Pulverized Coal Flow and Air Flow in Burner Lines," for Power-Gen '96; "The Worldwide Applicability of B\&W's Advanced Coal-Fired Low-Emission Boiler System," for the Thirteenth Annual International Pittsburgh Coal Conference; "Status of Phase II Subsystem Testing in Support of B\&W's Advanced Coal-Fired Low-Emission Boiler System" for the 1996 International Joint Power Generation Conference.

The following technical papers were presented; "Evaluation of Two Commercially Available Sensors for Use in Pulverized-Coal Burner Lines," at the Engineering Foundation Conference on Pneumatic and Hydraulic Conveying Systems; "B\&W's Advanced Coal-Fired Low-Emission Boiler System; An Update on Phase II Developments," at DOE's First Joint Power and Fuels Systems Contractors Conference;

\section{DISCLAIMER}

\footnotetext{
This report was prepared as an account of work sponsored by an agency of the United States Government. Neither the United States Government nor any agency thereof, nor any of their employees, makes any warranty, express or implied, or assumes any legal liability or responsibility for the accuracy, completeness, or usefulness of any information, apparatus, product, or process disclosed, or represents that its use would not infringe privately owned rights. Reference herein to any specific commercial product, process, or service by trade name, trademark, manufacturer, or otherwise does not necessarily constitute or imply its endorsement, recommendation, or favoring by the United States Government or any agency thereof. The views and opinions of authors expressed herein do not necessarily state or reflect those of the United States Government or any agency thereof.
} 


\section{NO $\mathrm{x}_{\mathbf{x}}$ Subsystem}

The goal of the $\mathrm{NO}_{\mathrm{x}}$ Subsystem is to achieve continuous operation of the Low-Emissions Boiler System (LEBS) at $\mathrm{NO}_{\mathrm{x}}$ emissions at or below $0.20 \mathrm{lb} / \mathrm{MBtu}$ through combustion techniques only, with a further target of $0.1 \mathrm{lb} \mathrm{NO} / \mathrm{MBtu}$ using supplementary advanced flue gas cleanup technologies if necessary. These goals place practical constraints that must be considered on the $\mathrm{NO}_{x}$ Subsystem design. Not only must the boiler be designed to achieve time-temperature mixing histories that minimize $\mathrm{NO}_{x}$, but it must also be designed to operate that way throughout its working lifetime. Therefore, $\mathrm{NO}_{\mathrm{x}}$ minimization strategies must be integrated into the control systems for every boiler component from the pulverizers to the stack. Furthermore, these goals must be met without increases in carbon loss and $\mathrm{CO}$ emissions from the levels achieved with current low-NO $\mathrm{N}_{\mathrm{x}}$ combustion systems. Therefore, the $\mathrm{NO}_{\mathrm{x}}$ Subsystem requires not only sound mechanical designs of burners, furnace surface, and staging air/fuel injectors, but also sensors and software to allow control of their operation. Through engineering analysis, experimental testing, and numerical modeling in Phase II, an advanced low-NO $\mathrm{N}_{\mathrm{x}}$ control system is being developed. The progress of these activities is presented in this report.

\section{II.1 Summary of Activities}

An engineering analysis of post-combustion flue gas cleanup processes as a part of the LEBS $\mathrm{NO}_{\mathrm{x}}$ subsystem was submitted for internal review. The information contained in this report will be incorporated into the Phase II final report. The focus of the study was to compare SCR and SNCR processes in terms of $\mathrm{NO}_{\mathrm{x}}$ reduction, operability, and economics.

An internal report was issued covering the results of the first $\mathrm{DRB}-4 \mathrm{Z}^{\mathrm{TM}}$ burner test series performed in the CEDF. This report will be incorporated into the Phase II final report. The information gained from the first series of burner tests was used to develop strategies for the second round of testing.

The second series of burner development tests were performed in the CEDF in May. Baseline conditions were repeatable, obtaining the same results achieved during the first burner test series. Preliminary results indicate that the new burner hardware pieces tested did not greatly effect the $\mathrm{NO}_{\mathrm{x}}$ reduction capabilities of the DRB- $4 \mathrm{Z}^{\mathrm{TM}}$ burner. A Kentucky \#9 coal was fired as a comparison to the Illinois \#6 design coal. Similar conditions were achieved with both test coals.

Final $\mathrm{NO}_{\mathrm{x}}$ predictions and burner visualization figures were completed for the CEDF scale DRB$4 Z^{\mathrm{TM}}$ modeling. These results have been used to evaluate the sensitivity of the burner to both hardware configuration and air distribution. 


\section{II.2 Key Accomplishments}

\section{II.2.1 Subsystem Test Unit}

B\&W's $100 \mathrm{MBtu} / \mathrm{hr}$ Clean Environment Development Facility (CEDF) is being used as the Combustion 2000 burner development Subsystem Test Facility. The advantage of using the CEDF for Subsystem scale testing is in the ability to test a near-full size burner in an environment which closely simulates a utility boiler. During the second test series, the only modification necessary on the CEDF was a modification to the burner throat to accommodate the advanced low-NO $\mathrm{N}_{\mathbf{x}}$ burner.

Hardware changes and various mixing devices were tested during the second round of Subsystem Testing. Operating conditions, including load and excess air, were varied for each hardware configuration and data were collected in terms of operating conditions, stack gaseous emissions, and fly ash samples.

Baseline testing was performed in the CEDF utilizing the DRB- $4 Z^{\mathrm{TM}}$ low-NO $\mathrm{N}_{\mathrm{x}}$ burner firing the LEBS Illinois \#6 design coal in a previously tested configuration. After some initial problems with the burner throat configuration, the baseline tests were found to be repeatable.

Two coals were fired during the burner testing, the Illinois \#6 design coal and a Kentucky \#9. The Kentucky \#9 coal has a similar composition as that of the Illinois \#6 coal, and was chosen to determine if the $\mathrm{CO}$ spikes seen during the first series of testing could be attributed to the Illinois \#6 coal or to the DRB- $4 Z^{\mathrm{TM}}$ burner. The DRB- $4 Z^{\mathrm{TM}}$ burner was also utilized during the Combustion $2000 \mathrm{SO}_{\mathrm{x}}$ Subsystem Testing, firing an Ohio blend coal. This blend of Ohio coals was also used during a previous test in the CEDF with the DRB-XCL ${ }^{\circledR}$ burner. Limited data was acquired while firing the Ohio blend (no parametric data), however, this information is being provided for an overall comparison.

Preliminary results indicate that the new burner hardware pieces tested did not greatly effect the $\mathrm{NO}_{\mathrm{x}}$ reduction capabilities of the $\mathrm{DRB}-4 \mathrm{Z}^{\mathrm{TM}}$ burner, nor were the levels of $\mathrm{CO}$ and unburned carbon effected. Some interesting trends were observed which led to further modifications of the burner to improve mixing, $\mathrm{NO}_{\mathbf{x}}$ reduction, and combustion efficiency.

An additional series of numerical combustion modeling cases were completed for several variations of the $100 \mathrm{MBtu} / \mathrm{hr}$ scale DRB- $4 \mathrm{Z}^{\mathrm{TM}}$ burner. Two-dimensional, axisymmetric models of the burner and burner tunnel were completed to provide more timely turnaround of the modeled cases. This series focused on redistribution of the secondary combustion air in the burner nearfield. The series also evaluated several potential hardware configurations for the May Subsystem Testing Campaign. In particular, the predicted results were used to identify combinations of burner hardware and secondary air distributions that resulted in attached or offset flames. Several of the predicted flames were validated during the CEDF test series. 


\section{III. $\quad \mathrm{SO}_{2} /$ Particulate/Air Toxics/Solid By-Product Subsystem}

The scope of the $\mathrm{SO}_{2}$ subsystem comprises the control of $\mathrm{SO}_{2}$, particulate matter, hazardous air pollutants (commonly called "air toxics"), and solid byproducts from the B\&W LEBS plant. The specific minimum performance requirements for the $\mathrm{SO}_{2}$ subsystem are:

- $\mathrm{SO}_{\mathrm{x}}$-- Less than $0.20 \mathrm{lb}$ ( $\mathrm{SO}_{2}$ equivalent)/MBtu for coals with sulfur levels of $3 \mathrm{lb}$ of sulfur per MBtu and no more than 0.067 times the sulfur content (lb/MBtu) for coals with less than $3 \mathrm{lb}$ of sulfur per MBtu.

- Particulate -- Less than $0.015 \mathrm{lb}$ particulate/MBtu

- Potential to comply with possible emissions control regulations for targeted air toxics.

- Produce environmentally benign solid byproduct.

- Integrate with other plant subsystems to yield optimal overall performance and cost.

In addition, the following performance targets have been established:

- $\mathrm{SO}_{\mathrm{x}}$-- Less than $0.10 \mathrm{lb}\left(\mathrm{SO}_{2}\right.$ equivalent)/MBtu for coals with sulfur levels of $3 \mathrm{lb}$ of sulfur per MBtu and no more than 0.0333 times the sulfur content (lb/MBtu) for coals with less than $3 \mathrm{lb}$ of sulfur per MBtu.

- Particulate -- Less than $0.01 \mathrm{lb}$ particulate/MBtu (B\&W plans to achieve $0.005 \mathrm{lb} / \mathrm{MBtu}$ )

On the basis of the results compiled during the concept selection process completed in Phase I, the Limestone Injection Dry Scrubbing (LIDS) process was selected for further development and evaluation in B\&W's LEBS project. The LIDS process is a cost-effective integration of three commercially proven flue gas cleanup technologies: furnace limestone injection, dry scrubbing, and pulse-jet fabric filtration. Through engineering analysis, experimental testing, and numerical modeling, a LIDS process is being developed that is capable of ultra-high $\mathrm{SO}_{2}$ removal and superior particulate control while addressing the potential issues of air toxic emissions and solid byproduct utilization. The progress of the LIDS activities follows.

\section{III.1 Summary of Activities}

Proposal efforts to the Ohio Coal Development Office (OCDO), the North Dakota Lignite Council, and the State of Illinois to gain their funding participation in the B\&W LEBS Phase IV proof-of-concept demonstration continued.

The $\mathrm{SO}_{2}$ subsystem participated in the Advisory Committee Meeting held May 17, 1996. Committee members present included: Bob Walton (AEP), David Stopek (Illinois Power), Tony Facchiano (EPRI), and Rob Hardman (Southern Company).

The $\mathrm{SO}_{2}$ subsystem participated in the DOE project review held on May 31, 1996.

The solid by-product cognizance effort continued. $B \& W$ is aggressively pursuing ways to reduce or utilize the solid waste produced by its various clean coal and FGD processes through a variety 
of in-house and externally-funded development programs. The effort will continue throughout the project. (Task 7.1)

The air toxics cognizance effort continued. B\&W is conducting a wide variety of air toxicsrelated research projects, and is closely following the regulatory process. The effort will continue throughout the project. (Task 7.1)

Numerical flow modeling of the commercial dry scrubber model was initiated. This model will be used to evaluate design variations, with predictions for impact on pressure drop, wall impingement, and mixing. This effort is covered under the key accomplishment section. (Task 7.3)

The second round of Phase II $100 \mathrm{MBtu} / \mathrm{hr}$ E-LIDS testing was completed June 17 - June 23, 1996 , at $100 \mathrm{MBtu} / \mathrm{hr}$ in the Clean Environment Development Facility. This effort is covered under the key accomplishment section. (Task 11.1)

\section{III.2 Key Accomplishments}

\section{II.2.1 Commercial Dry Scrubber Modeling}

Numerical modeling of the commercial dry scrubber design was initiated in May, beginning with the definition of the baseline geometry and operating conditions based on the Phase I modeling and testing work. The modeled vessel and outlet geometry is shown in Figure III.2.1.1, with representative mesh planes at the flue gas inlet plane and in the vessel outlet. The baseline geometry will be evaluated at full load conditions, before further evaluation is completed at both full and partial loads. Predicted results will provide information on flow distribution and mixing, slurry droplet trajectories and wall impingement, and particle moisture content at the dry scrubber exit. 
Figure III.2.1.1 - Geometry model and computational mesh for numerical flow predications of the commercial dry scrubber design.

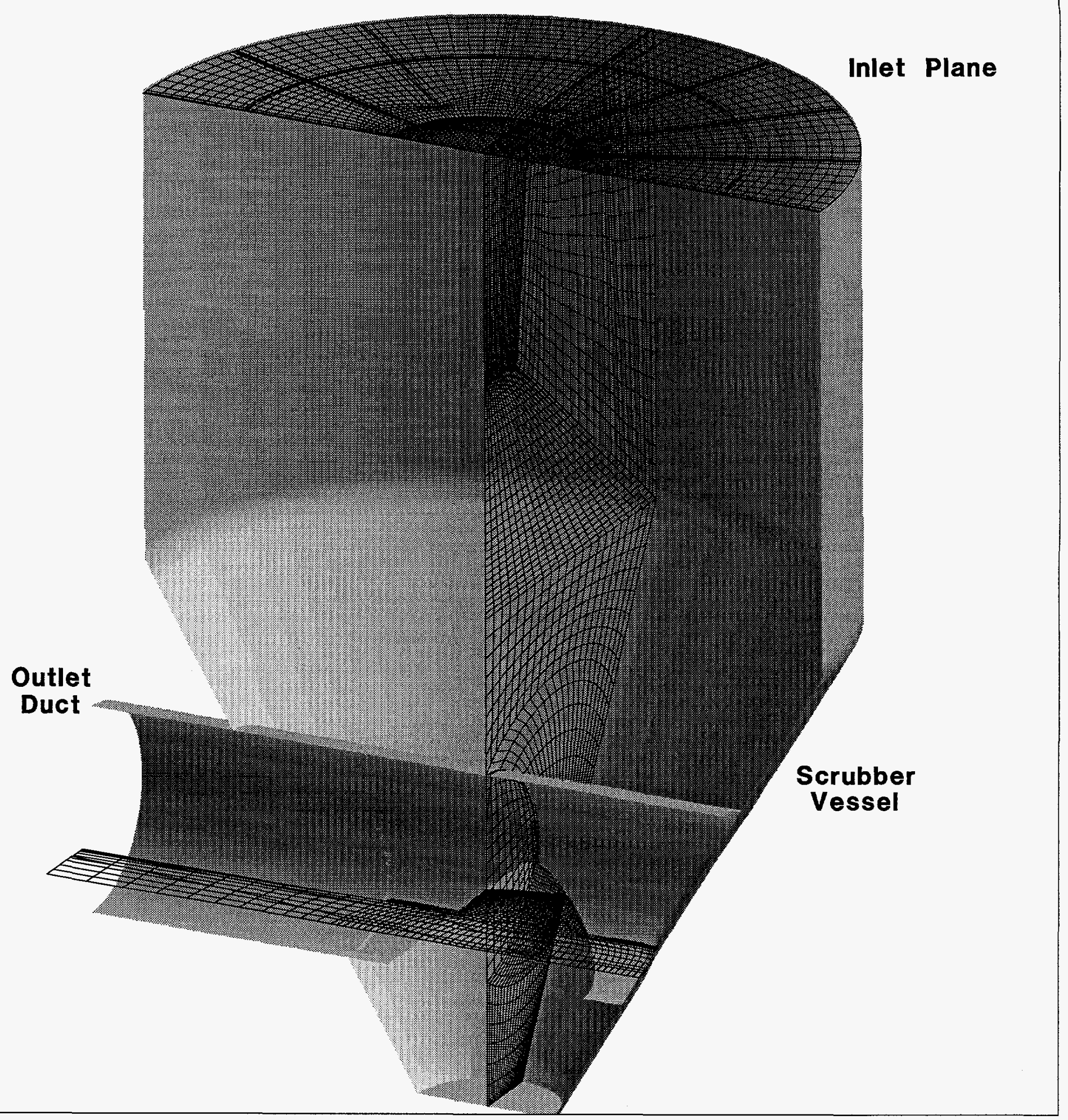

Page III-3 


\section{III.2.2 - E-LIDS Subsystem Test Series \#2}

The second round of Phase II E-LIDS testing was completed June 17 - June 23, 1996, at 100 $\mathrm{MBtu} / \mathrm{hr}\left(10 \mathrm{MW}_{\mathrm{e}}\right)$ in the Clean Environment Development Facility. The test series focused on achieving ultra-high $\mathrm{SO}_{2}$ capture, obtaining $\mathrm{SO}_{2}$ performance curves, and observing system operability.

Preliminary data show that the LEBS goal of $0.10 \mathrm{lb} \mathrm{SO}_{2} / \mathrm{MBtu}\left(98 \% \mathrm{SO}_{2}\right.$ removal) was achieved with the E-LIDS system. Approximate conditions used to achieve $98 \% \mathrm{SO}_{2}$ removal were: approach to saturation temperature $-10^{\circ} \mathrm{F}$, furnace calcium stoichiometry $-1.35 \mathrm{~mol} \mathrm{Ca} / \mathrm{mol} \mathrm{S}$, and slurry solids concentration 30-35\%. Approximate $\mathrm{SO}_{2}$ removals across each of E-LIDS unit operations were: furnace limestone injection - $35 \%$, dry scrubber - $55 \%$, and baghouse - $90 \%$ $\left(\left(\mathrm{SO}_{2}\right.\right.$ at the inlet of the unit operation - $\mathrm{SO}_{2}$ at the outlet of the unit operation)/SO $\mathrm{S}_{2}$ at the inlet of the unit operation). Figure III.2.2.1 shows the percentage of the total $\mathrm{SO}_{2}$ removal achieved at the outlet of each unit operation. Data reduction and analysis will continue during the months of July and August. A more detailed summary of the E-LIDS June 1996 test results will appear in the next quarterly report.

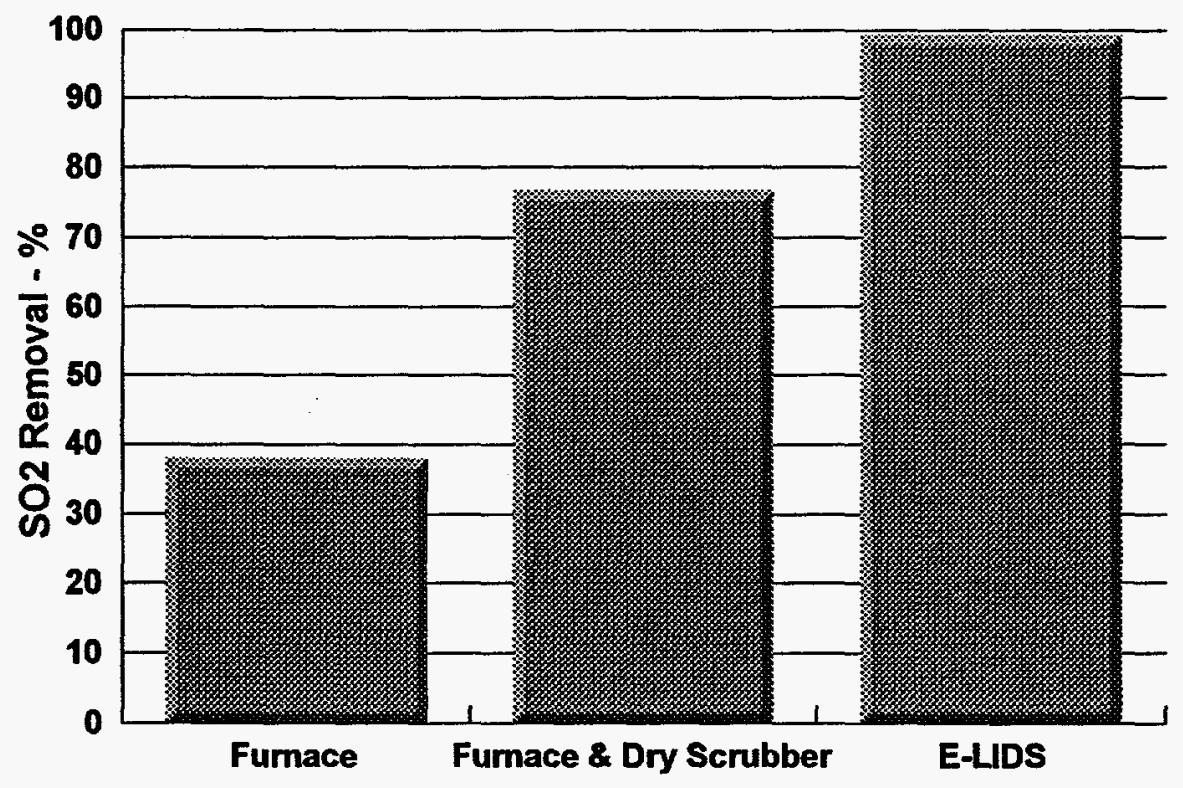

Figure III.2.2.1 - 10 MW $\mathrm{e}_{\mathrm{e}}$-LIDS $\mathrm{SO}_{2}$ Removal - PRELIMINARY - Test Jun21a2t 


\section{IV.1 Boiler Subsystem}

At the heart of the LEBS is the boiler. Within this advanced B\&W boiler, all of the low emission technologies are integrated. To achieve the net plant efficiency minimum requirement of $38 \%$ and the target of $42 \%$ at generating cost no greater than a conventional PC plant, the boiler must be designed not only to achieve the proper conditions for low $\mathrm{NO}_{\mathrm{x}}$ combustion with air staging and accommodate the in-furnace injection of the limestone for the E-LIDS ${ }^{\mathrm{TM}}$ process, but it must also efficiently capture the heat to produce high temperature steam at well above critical pressure. The steam conditions selected for the boiler are $4500 \mathrm{psi}, 1100^{\circ} \mathrm{F} / 1100^{\circ} \mathrm{F} / 1100^{\circ} \mathrm{F}$.

Since the steam-side pressure and main and reheat steam temperatures are higher than conventional cycles and operation of low $\mathrm{NO}_{\mathrm{x}}$ burners creates sub-stoichiometric conditions in portions the furnace, additional challenges are presented. Higher alloy materials must be used in the outlet portions of the superheater and reheater banks to obtain acceptable surface metal temperatures. In addition, materials must be selected that will resist corrosion since the surface of these outlet tubes will operate at temperatures which will allow the coal ash to remain molten on their surfaces. Consideration must also be given to furnace wall corrosion in the combustion zone. Thus, boiler design work has been identified to address the integration of the $\mathrm{NO}_{\mathrm{x}}$ and $\mathrm{SO}_{2}$ subsystems while applying B\&W's advanced supercritical boiler technology. Work addressing furnace corrosion based on gas-side sampling during burner testing is reported separately under the $\mathrm{NO}_{\mathrm{x}}$ subsystem.

\section{IV.1 Summary of Activities}

Work has been concentrated on setting surface for the boiler at 400MW conditions. The furnace size has been set as well as the amount of required heating surface.

Conditions have been established for the design of the airheater. A heat pipe airheater and a tubular design will be evaluated against the regenerative tri-sector design selected in Phase I to identify the most economical design. Because of the air leakage associated with a regenerative airheater, this option will be pursued only if the heat pipe and tubular turn out to be technically or economically unjustifiable.

\section{IV.2 Key Accomplishments}

\section{IV.2.1 Boiler Design Work}

The furnace and amount of heating surface has been set using B\&W design standards as well as input from the low NOx burner and E-LIDS testing. The boiler design is considered preliminary at this time due to the lack of a turbine reheat control load and some uncertainty in the method of limestone injection. The heating surface is currently set assuming no required limestone injection gas. This will be a significant challenge to accomplish, however, due to the effects of the injection gas diluting the furnace exit gas temperature, methods will be sought to achieve an even limestone 
distribution in the required location without the injection gas.

Information has been issued for the design and evaluation of a heat pipe air heater. This same information will be prepared for a tubular airheater. The air heater designs will be larger than those of Phase I due to the increased air and gas flows of a 400MW plant and the increased airheater inlet gas temperature of $674 \mathrm{~F}$ and holding the exit gas temperature to $248 \mathrm{~F}$ which is a requirement of the LIDS system.

\section{IV.2.2 Expanded Corrosion Work}

The 2000 hour laboratory corrosion test at $1000^{\circ} \mathrm{F}$, simulating the substoichiometric combustion environment on furnace walls, is in progress and will be completed in mid July. Analysis of the exposed samples will follow immediately after the test. For the two expanded laboratory corrosion tests which will be conducted for 5000 hours at $1300^{\circ} \mathrm{F}$ and $1500^{\circ} \mathrm{F}$, respectively, facility preparation and material procurement are being carried out at full speed. The $1300^{\circ} \mathrm{F}$ test was started at the end of June, and the $1500^{\circ} \mathrm{F}$ is expected to begin in mid July.

Two field test have also been included in the expanded corrosion study. Efforts to perform the first field test which involves installation of a test panel on the furnace wall of Allegheny Power Systems Unit \#2 at the Hatfield Ferry's Station are in progress. A proposal has been prepared and submitted to Electric Power Research Institute in June for cofunding this long-term field test. A favorable feedback has been received from EPRI on the technical approach of the field test. It is expected that EPRI will make a final decision on this proposal before August. Fabrication of the test panel will begin as soon as EPRI's funding approval is received.

The second field test involves analysis of the existing test panel in Unit \#4 of Dayton Power \& Light at the J. M. Stuart Station. Tube samples from the test panel have been retrieved and are being metallurgically examined. Analysis of these sample will be continued in the next quarter. 


\section{Balance of Plant Subsystem}

In order to develop an overall plant design and to evaluate plant efficiency and cost, B\&W subcontracted with Raytheon Engineers and Constructors of Denver, Colorado. Together a Phase I concept was developed that achieved the initial LEBS goal of $38 \%$ net plant efficiency. That design resulted in identification of a number of potential improvements to the turbine cycle and auxiliary equipment needed to meet the Phase II goal of $42 \%$ net plant efficiency.

\section{V.1 Summary of Activities}

Several full load turbine heat balances have been run for evaluation at a nominal $400 \mathrm{MWe}$. Different turbine manufacturers have been contacted for their input as well as personnel at the ELSAM project. Reheat control load is yet to be established.

Evaluation as to the method of limestone preparation has started. Manufacturers of limestone grinding equipment and plants to deliver prepared limestone have been contacted.

\section{V.2 Key Accomplishments}

A preliminary full load heat balance has been agreed upon for plant design. Several heat balances were run including a HARP cycle. At this time it appears that the HARP cycle is not economically feasible but further evaluation is needed. Currently the boiler design is not based on the HARP cycle heat balance. Input from turbine manufacturers indicate that our current cycle arrangement is achievable with today's technology.

The question of whether to have on site limestone preparation or to purchase prepared limestone is being evaluated. Quotes have been solicited from manufacturers of limestone grinding equipment as well as limestone quarries. At this point it is too early to tell which method is best. The question of the correct limestone particle size to inject into the furnace still remains unanswered but will be addressed in future testing at Alliance. The particle size has a significant effect on costs no matter which method is chosen. 


\section{Controls \& Sensors Subsystem}

In order to maintain low stack emissions and optimum boiler performance throughout the operating range and lifetime of the LEBS, a state-of-the-art integrated control system must be developed. This control system must include new sensors as well as old sensors used in new ways. It must make sense out of the data provided while initiating or directing the operator to take appropriate action. The control system will help assure that the LEBS will meet its stack emission, efficiency, availability, and cost of electricity goals.

The overall philosophy of the LEBS control system is to use conventional, state-of-the-art solutions to satisfy new control requirements. Existing sensors, hardware, and software are specified whenever possible and new measurements or advanced equipment are recommended for development only where necessary to assure the success of the project. The progress of the Controls \& Sensors Subsystem is as follows.

\section{VI.1 Summary of Activities}

B\&W collected optical, pressure, acoustic, and microwave data during the second series of DRB$4 Z^{\mathrm{TM}}$ CEDF tests conducted in May. Sixteen (16) channels of high-speed data were collected over a range of operating conditions and burner hardware configurations. Detailed analysis of the data was initiated in late May and continued through June. The FSA group also prepared for and participated in project update meetings with the LEBS Advisory Committee and with PETC.

\section{VI.2 Key Accomplishments}

\section{VI.2.1 On-line Coal Particle Size Measurement}

A Joint Nondisclosure Agreement was agreed to by both Babcock \& Wilcox and Insitec, Inc of San Ramon, California. Insitec's particle sizing instrumentation will be evaluated in B\&W's Solids Flow Facility for its capability to measure on-line the size distribution of pulverized coal.

\section{V1.2.2 Coal \& Air Flow Sensors Development}

For the May, 1996 test campaign in the CEDF, the microwave, the hot film and six acoustic emission sensors were installed on the 12-inch burner line. Test data was acquired for a seven day period, which included startup and steady state operation. The sensor output signals were recorded on digital audio tape to obtain detailed characteristics of the signal during a change in either air flow or coal flow in the burner line. Due to the large amount of data, analysis is not complete. However, the trends in the output signals are noteworthy. The hot film sensor does respond to changes in air flow. The air flow from the hot film was within about $10 \%$ of the air flow calculated by a orifice meter.

The calculated pulverized coal flow using both the microwave and hot film sensors was within about $25 \%$ of the coal flow provided by the CEDF equipment. The results are encouraging as further 
adjustment of the 'calibration correlations' should improve accuracy. The 'calibration correlations' used for the calculations was based on the setup in the Solids Flow Facility using a plastic material to simulate pulverized coal.

\section{VI.2.3 Acoustic Emission Sensor Development}

During the May, 1996 campaign in the CEDF, data was obtained from the microwave, hot film and acoustic emission sensors installed on the 12 -inch burner. The signal strength from the acoustic emission sensors was found to be dependent on both coal flow and air flow.

\section{VI.2.4 Flame Signature Analysis}

During mid-May, B\&W collected additional high-speed data from the second series of DRB- $4 Z^{\mathrm{TM}}$ CEDF tests. Like previous CEDF testing, the data was acquired using a TEAC RD-145T DAT data recorder and computer. Unlike previous testing, however, we collected 16 channels of data instead of just six (6). The 16 channels of data included signals from:

- an MKS Baratron pressure transducer located in the primary air/coal line,

- an MKS Baratron pressure transducer located in the windbox,

- a silicon photodiode sensor located in a sight port $2 / 3$ burner diameters downstream of the burner wall,

- a silicon photodiode sensor located in a sight port 2 burner diameters downstream of the burner wall,

- a silicon photodiode sensor located in a sight port 5 burner diameters downstream of the burner wall,

- an acoustic transducer located in a sight port 3 burner diameters downstream of the burner wall,

- a Forney DR6.1 flame scanner after in-head, high-pass filtering,

- a Forney DR6.1 flame scanner before in-head, high-pass filtering,

- an Endress-Hauser microwave meter located at an elbow in the primary air/coal line,

- a Kurz mass flow insertion probe located in the same spot as the microwave meter,

- two acoustic transducers located on an elbow of the primary air/coal pipe just upstream of the burner,

- two acoustic transducers located on the splash plate just upstream of the burner,

- a tachometer located on the coal feed belt, and

- a differential pressure transducer located on the inlet to the primary air fan.

The first six items listed are the same pieces of equipment used during previous testing to investigate burner dynamics. The Forney signals were added because any commercial implementation of the nonlinear dynamics and chaos technology will probably make use of existing burner sensors. The last eight items were added to investigate burner line coal flow dynamics. A total of 20 hours of highspeed data were recorded to tape during the test run. This data covered a range of burner hardware 
configurations, operating conditions, facility startups, facility shutdowns, and load changes.

The data analysis effort during this past quarter focused on the signals from the Forney flame scanner. In many boiler monitoring situations it may be convenient and/or cost effective to use signals from conventional flame scanners for monitoring flame quality. One difficulty in using these signals, however, is that such scanners are typically configured with internal high-pass filters that suppress low frequency fluctuations (e.g., less than $30 \mathrm{~Hz}$ ). Nevertheless, we expect that there should still be important flame quality information retained in the short-time-scale dynamic features that remain.

Figure VI.2.4.1 and VI.2.4.2 illustrate example dynamic comparisons between different burner configurations (at the same operating conditions) based on the standard flame scanner signals. As mentioned above, the flame scanner signals were generated by recording the output from a Forney model DR6.1 scanner mounted in a standard fashion on a sight tube in the burner. The output signal we used is the same one normally used to check flame status for safety purposes.

Our technique for characterizing the flame scanner signal is to first transform it using a movingwindow RMS (root-mean-square) and then looking for the occurrence of large amplitude excursions in the time- varying RMS. By transforming the signal with a moving-window RMS we obtain a result that reflects the time variation of fluctuation intensity (i.e., the time-varying "flicker" level). The presence of intensity excursions is then noted by looking for crossings of some predefined RMS threshold value. The relative frequency of these threshold crossings is next used to produce characteristic diagnostics, such as Figure VI.2.4.1 and VI.2.4.2. These figures represent the cumulative distributions of the observed time intervals between threshold crossings for the two burner configurations. Each figure is the result for different threshold crossing levels. Note that higher thresholds tend to accentuate lower frequency flicker events. From the figures it is clear that the two burner configurations have different flicker patterns. We therefore have confidence that traditional flame scanners can be used to provide previously unused dynamic information about the flame to state-of -the-art control systems.

\section{VI.2.5 Dynamic System Simulation}

A study of modeling packages resulting in final selection of Speedup was completed. A meeting was held to introduce the people that will be working on modeling to the Speedup software which is now running. Preparations for dynamically modeling the control system are underway. 


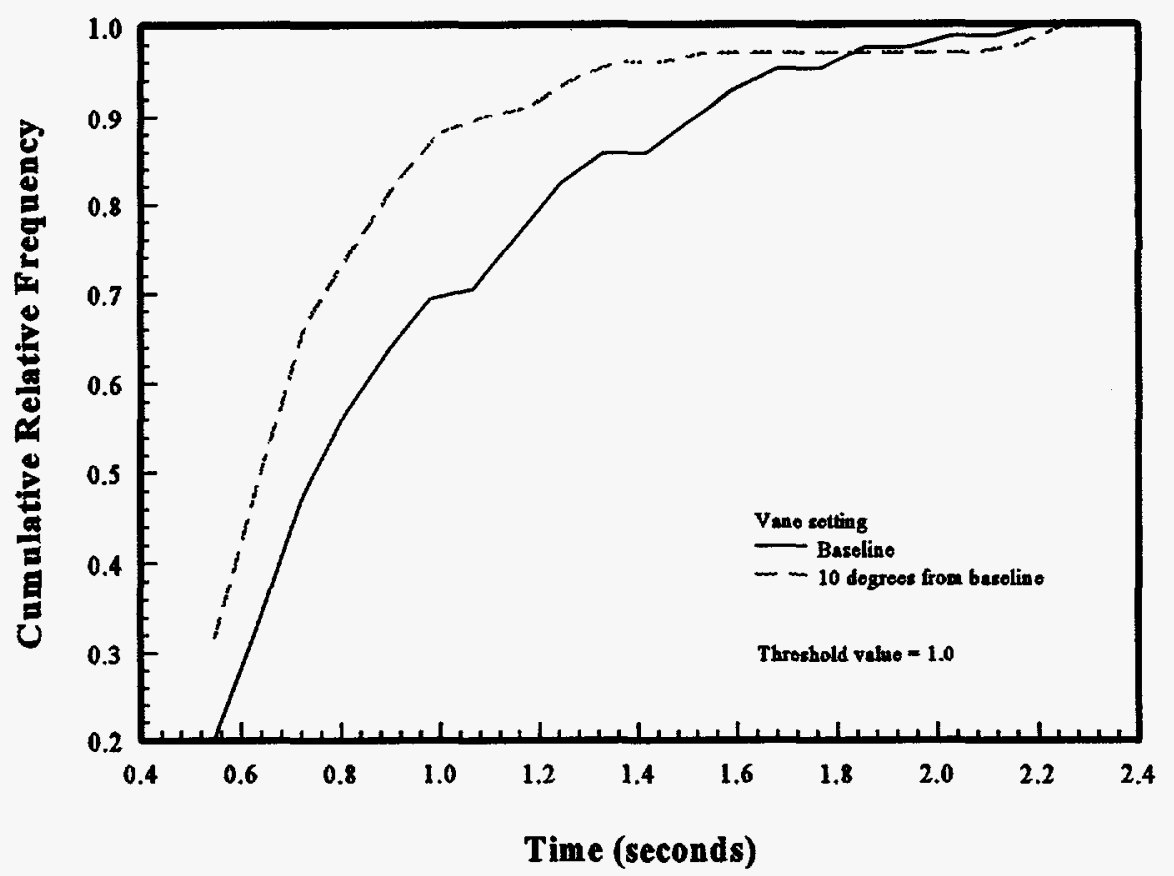

Figure VI.2.4.1. Low Threshold Dynamic Comparison

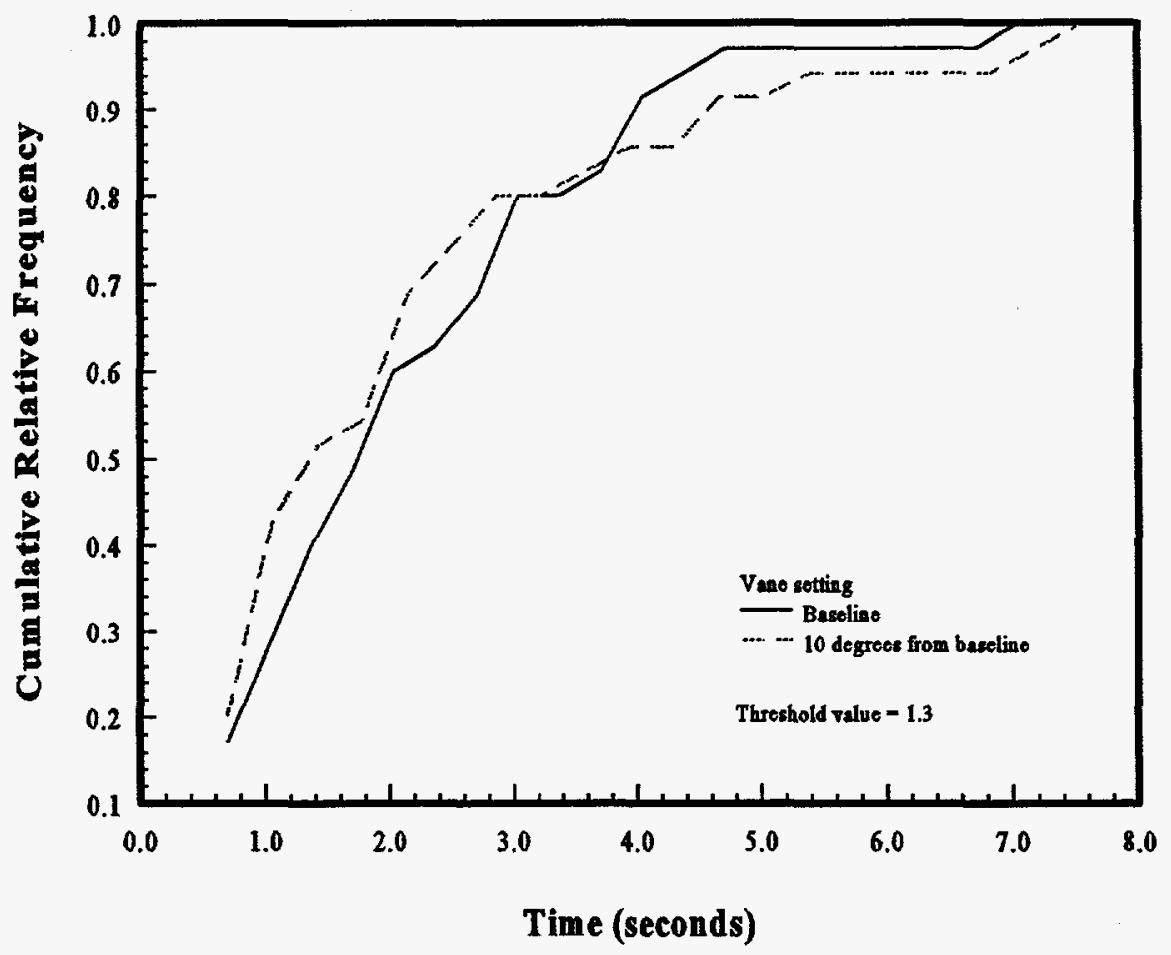

Figure VI.2.4.2. High Threshold Dynamic Comparison

Page VI - 4 